\title{
The influence of slightly and highly soluble carbonate salts on phase relations in hydrated calcium aluminate cements
}

\author{
Guillermo Puerta-Falla ${ }^{1}$, Magdalena Balonis ${ }^{2,3}$, Gwenn Le Saout ${ }^{4}$, Aditya Kumar ${ }^{1}$, \\ Melanie Rivera ${ }^{1}$, Gabriel Falzone ${ }^{1}$, Narayanan Neithalath ${ }^{5}$, and Gaurav Sant ${ }^{1,6, *}$ \\ ${ }^{1}$ Laboratory for the Chemistry of Construction Materials, Department of Civil and Environmental Engineering, University of \\ California, Los Angeles, CA, USA \\ ${ }^{2}$ Department of Materials Science and Engineering, University of California, Los Angeles, CA, USA \\ ${ }^{3}$ Institute for Technology Advancement, University of California, Los Angeles, CA, USA \\ ${ }^{4}$ Centre des Matériaux de l'École des Mines d'Alès (C2MA), École des mines d'Alès, Alès, France \\ ${ }^{5}$ School of Sustainable Engineering and the Built Environment (SSBE), Arizona State University, Tempe, AZ, USA \\ ${ }^{6}$ California Nanosystems Institute (CNSI), University of California, Los Angeles, CA, USA
}

\begin{abstract}
The addition of slightly $\left(\mathrm{CaCO}_{3}\right)$ and highly soluble $\left(\mathrm{Na}_{2} \mathrm{CO}_{3}\right)$ carbonate salts is expected to favor the formation of carboaluminate phases in hydrated calcium aluminate cements (CACs). A multi-method approach including X-ray diffraction, thermogravimetric analysis, and thermodynamic calculations is applied to highlight that the "conversion phenomena" in CACs cannot be mitigated by the formation of carboaluminate phases (monocarboaluminate: Mc and hemicarboaluminate: $\mathrm{Hc}$ ) which are anticipated to form following the addition of carbonate salts. Here, carboaluminate phase formation is shown to depend on three factors: (1) water availability, (2) carbonate content of the salts, and their ability to mobilize $\mathrm{CO}_{3}{ }^{2-}$ species in solution, and (3) lime content associated with the carbonate salt. The latter two factors are linked to the composition and solubility of the carbonate agent. It is concluded that limestone $\left(\mathrm{CaCO}_{3}\right)$, despite being a source of calcium and carbonate species, contributes only slightly to carboaluminate phase formation due to its low solubility and slow dissolution rate. Soluble carbonate salts $\left(\mathrm{Na}_{2} \mathrm{CO}_{3}\right)$ fail to boost carboaluminate phase formation as the availability of $\mathrm{Ca}^{2+}$ ions and water are limiting. Detailed thermodynamic calculations are used to elucidate conditions that affect the formation of carboaluminate phases.
\end{abstract}




\section{Introduction}

In recent years, the use of powdered limestone (calcite) has emerged as a route to reduce the ordinary portland cement (OPC) content of the binder phase in concrete. The kinetic and thermodynamic implications of limestone addition to OPC have been widely studied in terms of the filler effects of limestone and stabilization of ettringite (AFt) which prevents its conversion to monosulfoaluminate $\left(\mathrm{SO}_{4}-\mathrm{AFm}, \mathrm{Ms}\right)$. [1-12]. But studies describing the effects of limestone additions to calcium aluminate cements (CACs) are less common, likely on account of complexities in reactions in CACs, e.g., involving phase conversions, temperature dependence of phase equilibria, and the specialty use of CACs, as a result of which such cements account for only a small fraction of the total cement use [13-17].

The primary reactive compounds in CACs include monocalcium aluminate $\mathrm{CaO} \cdot \mathrm{Al}_{2} \mathrm{O}_{3} \quad(\mathrm{CA})$ and gehlenite $2 \mathrm{CaO} \cdot \mathrm{SiO}_{2} \cdot \mathrm{Al}_{2} \mathrm{O}_{3}\left(\mathrm{C}_{2} \mathrm{AS}\right)^{1}$. Since $\mathrm{C}_{2} \mathrm{AS}$ is slightly reactive at ambient temperatures, most studies simplify the hydration of CACs as the reaction of CA with water [18]. In water-rich systems (i.e., when $w / c>0.50, w / c$ : water-to-cement ratio, by mass) at ambient temperatures $\left(T<30^{\circ} \mathrm{C}\right)$, CACs hydrate to form $\mathrm{CAH}_{10}, \mathrm{C}_{2} \mathrm{AH}_{8}$, and $\mathrm{AH}_{3}$ as the initial ("early") hydration products (Eqs. 1-3a, $3 \mathrm{~b})$. The two former hydrates are termed as metastable, as in time they transform to $\mathrm{C}_{3} \mathrm{AH}_{6}$ which coexists with $\mathrm{AH}_{3}$, and stratlingite phases at "mature" times [19]. Since this nature of phase transformations involves the expulsion of water from the solids, the resulting accumulation of water in the microstructure results in an increase in porosity, and a detrimental reduction in the mechanical properties [20-22]. This process is termed as "conversion" [16].

Recently, Falzone et al. [13] showed that the reaction pathway involving the formation of the metastable hydrates (i.e., $\mathrm{CAH}_{10}, \mathrm{C}_{2} \mathrm{AH}_{8}$ ) and their conversion to $\mathrm{C}_{3} \mathrm{AH}_{6}$ can be bypassed by the addition of calcium nitrate $\left(\mathrm{Ca}\left(\mathrm{NO}_{3}\right)_{2}\right)$. This is due to the formation of the $\mathrm{NO}_{3}$-AFm phase, which acts to circumvent/bypass the conversion process.

\footnotetext{
${ }^{1}$ Standard cement chemistry notation is used. As per this simplified notation: $\mathrm{C}=\mathrm{CaO}, \mathrm{A}=\mathrm{Al}_{2} \mathrm{O}_{3}, \quad \mathrm{~F}=\mathrm{Fe}_{2} \mathrm{O}_{3}$, $\mathrm{S}=\mathrm{SiO}_{2}, \mathrm{CS}=\mathrm{CaSO}_{4} \cdot 2 \mathrm{H}_{2} \mathrm{O}, \mathrm{H}=\mathrm{H}_{2} \mathrm{O}$, and $\overline{\mathrm{C}}=\mathrm{CO}_{2}$.
}

$\mathrm{CA}+10 \mathrm{H} \rightarrow \mathrm{CAH}_{10}$

$2 \mathrm{CAH}_{10} \rightarrow \mathrm{C}_{2} \mathrm{AH}_{8}+\mathrm{AH}_{3}+9 \mathrm{H}$

$2 \mathrm{CA}+11 \mathrm{H} \rightarrow \mathrm{C}_{2} \mathrm{AH}_{8}+\mathrm{AH}_{3}$

$3 \mathrm{C}_{2} \mathrm{AH}_{8} \rightarrow 2 \mathrm{C}_{3} \mathrm{AH}_{6}+\mathrm{AH}_{3}+9 \mathrm{H}$

$3 \mathrm{CA}+12 \mathrm{H} \rightarrow \mathrm{C}_{3} \mathrm{AH}_{6}+2 \mathrm{AH}_{3}$

It is postulated that similar to calcium nitrate, limestone and sodium carbonate, due to their ability to provision $\mathrm{CO}_{3}{ }^{2-}$ ions and the potential to stabilize the $\mathrm{CO}_{3}$-AFm compounds (i.e., monocarboaluminate, $\mathrm{Mc}$, and hemicarboaluminate, $\mathrm{Hc}$, as shown in Eqs. 4-6), should also be able to prevent conversion $[8,23]$. Based on this concept, Luz and Pandolfelli [24] showed that the addition of $\mathrm{CaCO}_{3}$ to $\mathrm{CACs}$ does result in the formation of the carboaluminate phases which can somewhat inhibit phase conversion. However, recent studies have shown that the reaction of limestone with CACs is kinetically hindered in spite of being thermodynamically favored [12]. It is therefore postulated that for carboaluminate phase formation to be enhanced, a carbonate source with high solubility, and fast dissolution, i.e., a soluble carbonate salt similar to $\mathrm{Ca}\left(\mathrm{NO}_{3}\right)_{2}$, needs to be provisioned. Based on this idea, this study examines the influences of two carbonate salts of low (limestone, $\mathrm{CaCO}_{3}$ ) and high solubility (sodium carbonate, $\mathrm{Na}_{2}$ $\mathrm{CO}_{3}$ ) on hydrated phase relations in CACs. The role of water availability is discussed in terms of impacts on carboaluminate phase formation. Special focus is paid to understand if the supply of a suitable carbonate source can indeed suppress phase conversion reactions in calcium aluminate cements.

$$
\begin{aligned}
& 3 \mathrm{CA}+\mathrm{C} \overline{\mathrm{C}}+17 \mathrm{H} \rightarrow \mathrm{C}_{4} \mathrm{~A} \overline{\mathrm{C}} \mathrm{H}_{11}+2 \mathrm{AH}_{3} \\
& \mathrm{C}_{3} \mathrm{AH}_{6}+\mathrm{C} \overline{\mathrm{C}}+5 \mathrm{H} \leftrightarrow \mathrm{C}_{4} \mathrm{~A} \overline{\mathrm{C}} \mathrm{H}_{11} \\
& \mathrm{C}_{3} \mathrm{~A}+0.5 \mathrm{C} \overline{\mathrm{C}}+0.5 \mathrm{CH}+11.5 \mathrm{H} \rightarrow \mathrm{C}_{4} \mathrm{~A}_{0.5} \mathrm{H}_{12}
\end{aligned}
$$

\section{Materials and methods}

A commercially available grey calcium aluminate cement (CAC) Secar 51 that is produced by Kerneos Aluminate Technologies was used. The oxide composition of the CAC as determined by X-ray fluorescence (XRF) in mass \% was as follows: $4.9 \% \mathrm{SiO}_{2}$, $52.1 \% \mathrm{Al}_{2} \mathrm{O}_{3}, 2.3 \% \mathrm{Fe}_{2} \mathrm{O}_{3}, 39.8 \% \mathrm{CaO}, 0.60 \% \mathrm{MgO}$, $0.07 \% \mathrm{Na}_{2} \mathrm{O}$, and $0.31 \% \mathrm{~K}_{2} \mathrm{O}$. The mineralogical (phase) composition of the CAC as determined from 
Rietveld analysis of its X-ray diffraction patterns in mass $\%$ was as follows: $73.3 \% \mathrm{CA}, 18.1 \% \mathrm{C}_{2} \mathrm{AS}$, $4.9 \% \mathrm{CT}, 1.5 \% \mathrm{C}_{3} \mathrm{FT}, 0.6 \% \mathrm{C}_{2} \mathrm{~F}, 0.8 \% \mathrm{CaO}$, and $0.8 \% \mathrm{Fe}_{2} \mathrm{O}_{3}$. A nominally pure limestone powder $\left(>95 \% \mathrm{CaCO}_{3}\right)$ was sourced from OMYA A.G. ${ }^{2}$ Analytical reagent-grade sodium carbonate was purchased from Sigma-Aldrich (CAS Number: 497-19-8).

A series of cementitious mixtures (Table 1) were prepared using de-ionized (DI) water at 3 different water-to-solid ratios $(w / s=0.40,0.45$, and 0.70 , by mass) as described in ASTM C305 [25]. In samples where CAC was replaced by limestone, the CAC and limestone were "dry mixed" prior to the addition of water. For blends where CAC was replaced by sodium carbonate, sodium carbonate was dissolved in water, and the CAC was then mixed into this solution. It should be noted that the $w / s$ listed corresponds to the water-to-solid (i.e., CAC, sodium carbonate and limestone) ratio on a mass basis. The replacement of CAC by a carbonate source alters the (a) equivalent carbon dioxide-to-aluminum oxide $\left(\mathrm{CO}_{2-\mathrm{eq}} / \mathrm{Al}_{2} \mathrm{O}_{3}\right)$ ratio, (b) calcium-to-aluminum oxide $\left(\mathrm{CaO} / \mathrm{Al}_{2} \mathrm{O}_{3}\right)$ ratio, and (c) equivalent carbon dioxide-to-calcium oxide $\left(\mathrm{CO}_{2-\mathrm{eq}} / \mathrm{CaO}\right)$ ratio (all on a mass basis). Trends in these ratios as a function of CAC replacement level are shown in Fig. 1.

The particle size distributions (PSDs, Fig. 1d) of all the solids were measured using a Beckman Coulter Static Light Scattering Analyzer (LS13-320). Powders were dispersed to their primary particles by sonication in isopropanol. The uncertainty in the light scattering analysis was around $6 \%$ based on six replicates and assuming the refractive index of the CAC, limestone, and anhydrous $\mathrm{Na}_{2} \mathrm{CO}_{3}$ to be 1.7, 1.69 , and 1.535 , respectively [26].

The compressive strength of the $w / s=0.45 \mathrm{mix}$ tures (see Table 1) was measured at $1,3,7,28$, and 90 days using cubic specimens $(50 \times 50 \times 50 \mathrm{~mm})$ cured at $25 \pm 1{ }^{\circ} \mathrm{C}$ in lime water as described in ASTM C109 [25]. The strength reported is the average of three specimens cast from the same mixing batch.

\footnotetext{
${ }^{2}$ Certain commercial materials and equipment are identified to adequately specify experimental procedures. In no case does, such identification implies recommendation or endorsement by University of California, Los Angeles, École des Mines d'Alès, or Arizona State University, nor does it imply that the items identified are necessarily the best available for the purpose.
}

Table 1 An overview of the cementitious formulations used in this study

\begin{tabular}{llll}
\hline Mixture ID & $w / s$ & $\begin{array}{l}\text { Replacement } \\
\text { by } \mathrm{CaCO}_{3}(\%)\end{array}$ & $\begin{array}{l}\text { Replacement } \\
\text { by } \mathrm{Na}_{2} \mathrm{CO}_{3}(\%)\end{array}$ \\
\hline SEC & 0.45 & 0 & 0 \\
10LSEC & $0.40,0.45,0.70$ & 10 & 0 \\
30LSEC & 0.45 & 30 & 0 \\
50LSEC & 0.45 & 50 & 0 \\
10NSEC & $0.40,0.70$ & 0 & 10 \\
30NSEC & 0.70 & 0 & 30 \\
\hline
\end{tabular}

X-ray diffraction (XRD) patterns were obtained on finely powdered samples at desired ages using a Bruker D8 Advance diffractometer in a $\theta-\theta$ configuration using $\mathrm{Cu}-\mathrm{K} \alpha$ radiation $(\lambda=1.54 \AA$ ). The samples were scanned between $5^{\circ}$ and $70^{\circ}(2 \theta$, degrees) in continuous mode with an integrated step scan of $0.017^{\circ}(2 \theta$, degrees) using a VANTEC detector. The total time required for acquisition of the $\mathrm{X}$-ray diffraction pattern was around $12 \mathrm{~min}$. A fixed divergence slit of $0.50^{\circ}$ was used during data acquisition. Care was taken to minimize preferred orientation errors by texturing the surfaces of the sample. Information on the X-ray structures of anhydrous and hydrated crystalline phases was sourced from standard databases (ICDD [27]) or the literature [28]. The anhydrous CAC was analyzed using a protocol described by Le Saout et al. [29].

A Perkin Elmer STA 6000 simultaneous thermal analyzer (TGA/DTG/DTA) equipped with a Pyris data acquisition interface was used to identify and quantify solid phases present in the cementitious mixtures. The temperature and mass sensitivity of this instrument are $\pm 0.25^{\circ} \mathrm{C}$ and $\pm 0.1 \mu \mathrm{g}$, respectively. To arrest hydration, solvent exchange was performed using isopropanol wherein at a desired age, hydrated pastes were crushed to a size less than $5 \mathrm{~mm}$ and submerged in isopropanol for 14 days, with isopropanol being replaced every 7 days. Following such solvent exchange, samples were placed under vacuum in a desiccator to remove the solvent for another 7 days. During measurement, powder samples were placed in pure aluminum oxide crucibles under the UHP- $\mathrm{N}_{2}$ purge at a flow rate of $20 \mathrm{ml} / \mathrm{min}$ and heated at a rate of $10{ }^{\circ} \mathrm{C}$ per minute over a temperature range from 35 to $975{ }^{\circ} \mathrm{C}$. The weight loss (TG) and differential weight loss (DTG) patterns acquired were used to quantify the amount of $\mathrm{CaCO}_{3}$ present in the system. It should be noted 


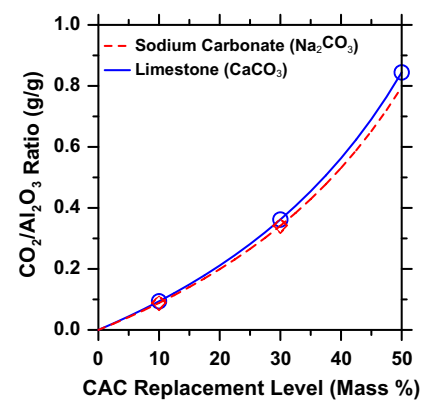

(a)

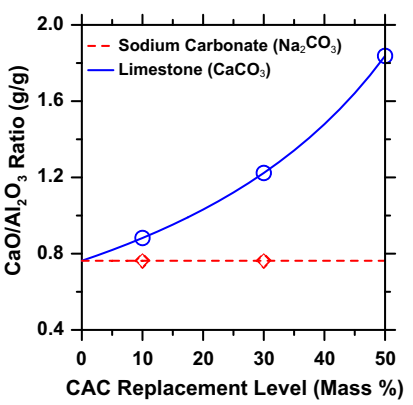

(b)

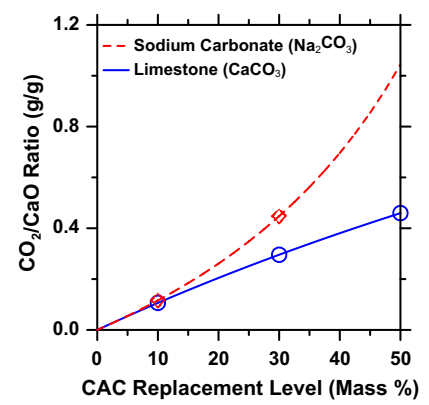

(c)

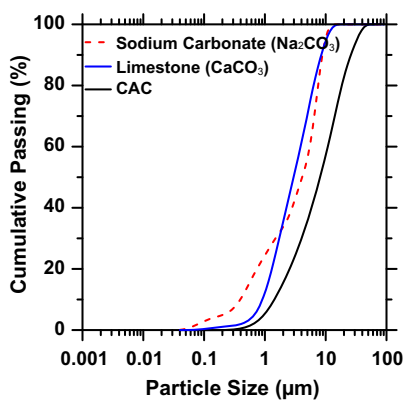

(d)

Figure 1 a Carbon dioxide equivalent-to-aluminum oxide $\left(\mathrm{CO}_{2}\right.$ -eq $\left./ \mathrm{Al}_{2} \mathrm{O}_{3}\right)$, b calcium-to-aluminum oxide $\left(\mathrm{CaO} / \mathrm{Al}_{2} \mathrm{O}_{3}\right)$, and $\mathbf{c}$ carbon dioxide equivalent-to-calcium oxide $\left(\mathrm{CO}_{2-\mathrm{eq}} / \mathrm{CaO}\right)$ mass ratios

that the quantity of $\mathrm{CaCO}_{3}$ is presented as a percentage of the phase present per dry mass of paste $(\%$ dry mass).

\section{Thermodynamic calculations}

Thermodynamic calculations were carried out using a geochemical speciation program, GEMS-PSI, Gibbs Energy Minimization Software, ver. 2.3 [30]. GEMSPSI uses the initial mixture proportions represented in the form of the simple oxides present in the solid precursors and the water content, as inputs, and applies a convex programming approach in conjunction with data of the thermodynamic properties of phases (solids, liquid, and air) to compute equilibrium phase balances and ion speciation in a multicomponent system. The input oxide composition of the CAC was obtained from the XRF data. To simulate different levels of CAC reaction, the oxides present in the CAC were allowed to react in incremental steps of $10 \%$, from 0 to $100 \%$ reaction with the total amount of water and carbonate source present. It should be noted that this approach does not consider the kinetics, i.e., the rate of reaction of the different phases in a CAC. Rather, it seeks to understand the evolution of phase balances with increasing reaction extent-assuming that in any given reaction step, the reactants are completely transformed to suitable products, to minimize the free energy. Thus, this "fractional reaction" approach elucidates the development of hydrated phases in the style of a step-wise reaction sequence [31-33].

as a function of the $\mathrm{CAC}$ replacement level for each carbonate source. d Particle size distributions (PSDs) of the solid reactants used in this study.

Thermodynamic data of solid and aqueous species were sourced from the built-in GEMS-PSI (NAGRA) database of minerals, and amended with additional data relevant to cementitious systems as embedded in the CEMDATA07 database [14, 34-37]. The thermodynamic database was further expanded to consider gaylussite and thermonatrite as these phases were found to exist in $\mathrm{Na}_{2} \mathrm{CO}_{3}$-bearing blends [38] (see Table 2). Natron was also included to determine if this phase has a potential to form, and persists in blends containing higher $\mathrm{Na}_{2} \mathrm{CO}_{3}$ contents. The Gibbs free energy $\left(\Delta_{\mathrm{f}} \mathrm{G}^{0}\right)$ of formation at $T=25^{\circ} \mathrm{C}$ and $p=1$ bar along with other thermodynamic properties (e.g., enthalpy and entropy of formation) and the molar volumes of these phases were adapted from the THERMODDEM database [38] (Table 2). All simulations are carried out at $p=1$ bar and $T=25^{\circ} \mathrm{C}$ in $\mathrm{CO}_{2}$-free air. It is important to note that the simulations presented do not account for the influences of temperature change on phase relations, e.g., due the exothermic nature of CAC hydration. The simulations presented apply to two different scenarios: (i) "mature" time scales where $\mathrm{C}_{3} \mathrm{AH}_{6}$ and $\mathrm{AH}_{3}$ are the stable hydrates that persist, and (ii) "early" times where the metastable hydrates such as $\mathrm{CAH}_{10}, \mathrm{C}_{2} \mathrm{AH}_{8}$, and $\mathrm{AH}_{3}$ persist, while the $\mathrm{C}_{3} \mathrm{AH}_{6}$ phase is suppressed from forming. For example, the mature age scenario is simulated by restricting the formation of the metastable hydrates and vice versa. For the sake of clarity, since the present work seeks to understand the influences of carbonate salts on preventing conversion (i.e., preventing the $\mathrm{C}_{3} \mathrm{AH}_{6}$ phase from forming at later times), only results corresponding to mature systems are presented. 
Table 2 Thermodynamic data for relevant compounds at $T=25{ }^{\circ} \mathrm{C}$ and $p=1$ bar which are used in calculations of phase equilibria

\begin{tabular}{|c|c|c|c|c|c|c|c|c|}
\hline Phase & $\begin{array}{l}\Delta_{\mathrm{f}} G^{0} \\
{[\mathrm{~kJ} / \mathrm{mol}]}\end{array}$ & $\begin{array}{l}\Delta_{\mathrm{f}} H^{0} \\
{[\mathrm{~kJ} / \mathrm{mol}]}\end{array}$ & $\begin{array}{l}S^{0} \\
{[\mathrm{~J} / \mathrm{K} / \mathrm{mol}]}\end{array}$ & $a_{0}$ & $a_{1}$ & $a_{2}$ & $a_{3}$ & $\begin{array}{l}V \\
{\left[\mathrm{~cm}^{3} / \mathrm{mol}\right]}\end{array}$ \\
\hline $\mathrm{C}_{3} \mathrm{AH}_{6}$ & -5010.1 & -5540 & 419 & 292 & 0.561 & & & 150 \\
\hline $\mathrm{C}_{4} \mathrm{AH}_{13}$ (hydroxy-AFm) & -7326.6 & -8302 & 700 & 711 & 1.047 & & -1600 & 274 \\
\hline $\mathrm{C}_{4} \mathrm{AcH}_{11}$ monocarboaluminate & -7337.5 & -8250 & 657 & 618 & 0.982 & -2590000 & & 261 \\
\hline $\mathrm{C}_{4} \mathrm{Ac}_{0.5} \mathrm{H}_{12}$ hemicarboaluminate & -7336 & -8270 & 713 & 664 & 1.014 & -1300000 & -800 & 285 \\
\hline $\mathrm{C}_{2} \mathrm{ASH}_{8}$ (strätlingite) & -5705.1 & -6360 & 546 & 438 & 0.749 & -1130000 & -800 & 216 \\
\hline $\mathrm{M}_{4} \mathrm{AH}_{10}(\mathrm{OH}-$ hydrotalcite $)$ & -6394.56 & -7196 & 549 & -364 & 4.21 & 3750000 & 629 & 220 \\
\hline $\mathrm{M}_{4} \mathrm{AcH}_{9}\left(\mathrm{CO}_{3}\right.$-hydrotalcite $)$ & -6580.15 & -7374 & 551 & -382 & 4.24 & 4320000 & 629 & 220 \\
\hline Brucite, $\operatorname{Mg}(\mathrm{OH})_{2}$ & -832.23 & -923 & 63 & 101 & 0.017 & -2560000 & & 25 \\
\hline Water $\left(\mathrm{H}_{2} \mathrm{O}\right)$ & -237.2 & -286 & 70 & 75 & & & & 18 \\
\hline $\mathrm{SiO}_{2}$ (amorphous) & -848.9 & -903 & 41 & 47 & 0.034 & -1130000 & & 29 \\
\hline $\mathrm{Fe}(\mathrm{OH})_{3}$ (microcrystalline) & -711.6 & -844 & 88 & 28 & 0.052 & & & 34 \\
\hline $\mathrm{Al}(\mathrm{OH})_{3}$ (amorphous) & -1143.21 & -1281 & 70 & 36 & 0.191 & & & 32 \\
\hline $\mathrm{Al}(\mathrm{OH})_{3}$ (gibbsite) & -1151 & -1289 & 70 & 36 & 0.191 & & & 32 \\
\hline Portlandite, $\mathrm{Ca}(\mathrm{OH})_{2}, \mathrm{CH}$ & -897 & -985 & 83 & 187 & -0.02 & & -1600 & 33 \\
\hline Calcite, $\mathrm{CaCO}_{3}, \mathrm{CC}$ & -1129.2 & -1207 & 93 & 105 & 0.022 & -2590000 & & 37 \\
\hline Gypsum, $\mathrm{CaSO}_{4} \cdot 2 \mathrm{H}_{2} \mathrm{O}$ & -1797.8 & -2023 & 194 & 91 & 0.318 & & & 75 \\
\hline Gaylussite, $\mathrm{Na}_{2} \mathrm{Ca}\left(\mathrm{CO}_{3}\right)_{2} \cdot 5 \mathrm{H}_{2} \mathrm{O}$ [38] & -3372 & -3834 & 387 & $\mathrm{a}$ & & & & 148 \\
\hline Thermonatrite, $\mathrm{Na}_{2} \mathrm{CO}_{3} \cdot \mathrm{H}_{2} \mathrm{O}[38]$ & -1286.2 & -1430 & 168 & 149 & & & & 54.8 \\
\hline Natron $\mathrm{Na}_{2} \mathrm{CO}_{3} \cdot 10 \mathrm{H}_{2} \mathrm{O}[38]$ & -3427.9 & -4079 & 565 & 550 & & & & 196 \\
\hline
\end{tabular}

$a_{0}, a_{1}, a_{2}, a_{3}$ are empirical coefficients of the heat capacity equation: $C_{\mathrm{p}}=a_{0}+a_{1} \mathrm{~T}+a_{2} \mathrm{~T}^{-2}+a_{3} \mathrm{~T}^{-0.5}$; no value $=0$.

a not available

\section{Experimental results and discussion}

\section{Influence of limestone (slightly soluble carbonate) additions}

Figure 2a shows compressive strength evolutions of mixtures prepared with various levels of CAC replaced by limestone. At any given age, the compressive strength reduces as the amount of limestone replacing CAC is increased. To account for dilution (i.e., reduction of the CAC content), the compressive strength at 90 days was plotted as a function of the CAC fraction in the pastes (Fig. 2b). Despite the reduction in strength with a decrease in the CAC

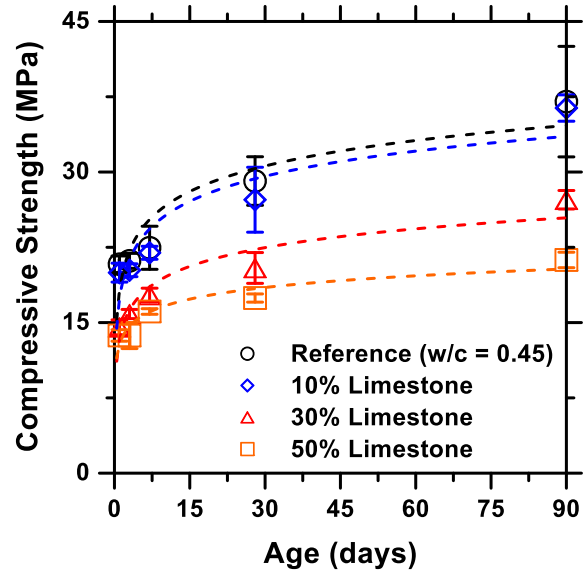

(a)

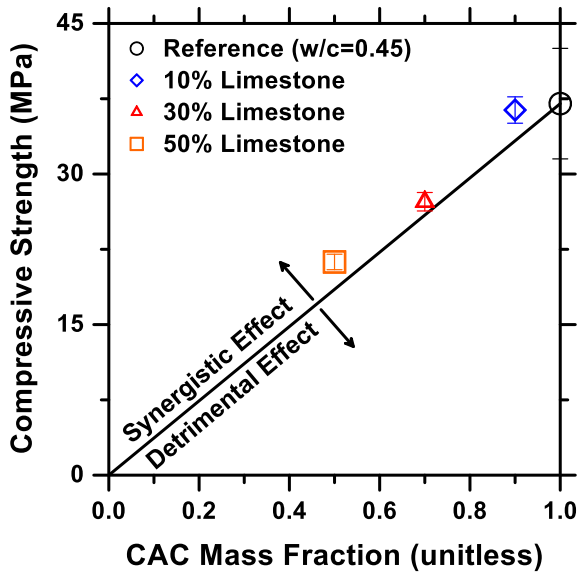

Figure 2 Compressive strength of CAC pastes: $\mathbf{a}$ as a function of age for various levels of $\mathrm{CAC}$ replacement by limestone and $\mathbf{b}$ after 90 days of hydration as a function of the CAC mass fraction in the binder. For all the mixtures illustrated in the figure, $w / s=0.45$. 
content, the strength values remain somewhat above the "dilution line." This implies that the inclusion of limestone results in synergistic effects-which, however, are not sufficient to prevent reductions in strength caused due to dilution. As noted in Fig. 2a, all mixtures show a steady increase in strength with age-at ambient curing temperatures $\left(25^{\circ} \mathrm{C}\right)$, a low temperature which is known to delay the onset of the conversion process [24, 39]. Furthermore, Scrivener et al. [16] noted that compressive strength development in large CAC samples (i.e., more than a few centimeters thick) is different from that in thinner samples, due to significant heat generation which results in accelerated conversion reactions in the former. After conversion has been completed, it is postulated that further strength gain may be associated with the formation of increasing quantities of $\mathrm{C}_{3} \mathrm{AH}_{6}, \mathrm{Mc}$, or due to the hydration of residual unhydrated CAC [16] as water released from the metastable hydrates becomes available for reaction.

Figure 3 shows the development of phase assemblages, assessed by qualitative $\mathrm{XRD}$, in blends where $10 \%$ (by mass) of the CAC is replaced by limestone. It was observed that an increase in the water content $(w / s)$ results in increased monocarboaluminate (Mc) formation (i.e., based on simple peak height comparisons), and the reduced formation of $\mathrm{C}_{3} \mathrm{AH}_{6}$-an outcome which may be associated with inhomogeneous water distributions in the microstructure. The enhanced formation of Mc occurs in conjunction with the consumption of $\mathrm{CaCO}_{3}$ (as also verified from TGA quantifications; Fig. 4), since the latter is a reactant in the formation of Mc. The consumption of $\mathrm{CaCO}_{3}$ is accelerated by increasing water content as more limestone solubilizes increasing water availability. For example, after 90 days of hydration in a blend which initially contained 10 mass\% limestone, there is less than 2 mass\% unreacted limestone present in a system prepared at $w / s=0.70$, while around $5 \mathrm{mass} \%$ limestone persists in a system prepared at

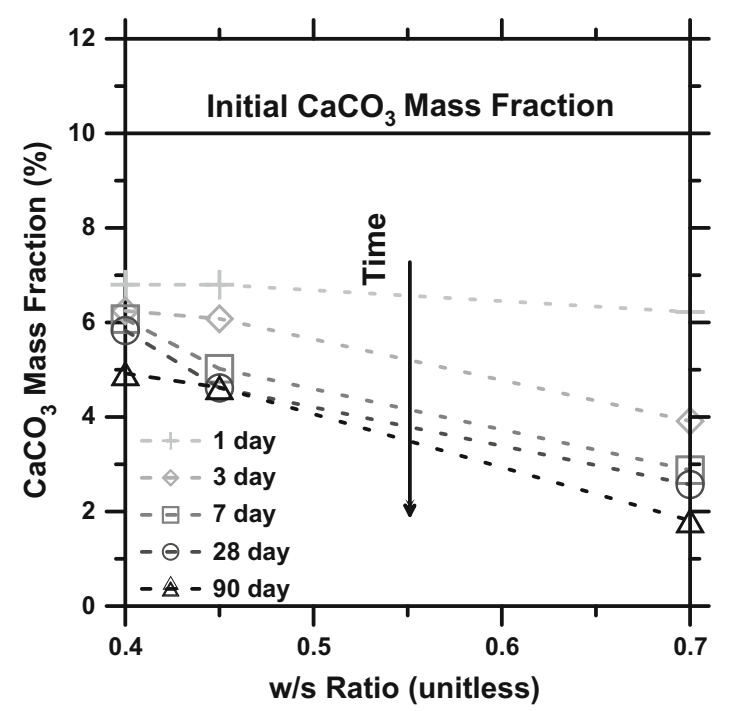

Figure 4 Residual $\mathrm{CaCO}_{3}$ content quantified using thermal analysis (TGA/DTG) in CAC-limestone blends wherein 10 mass $\%$ of the CAC was replaced by limestone at different $w / s$.

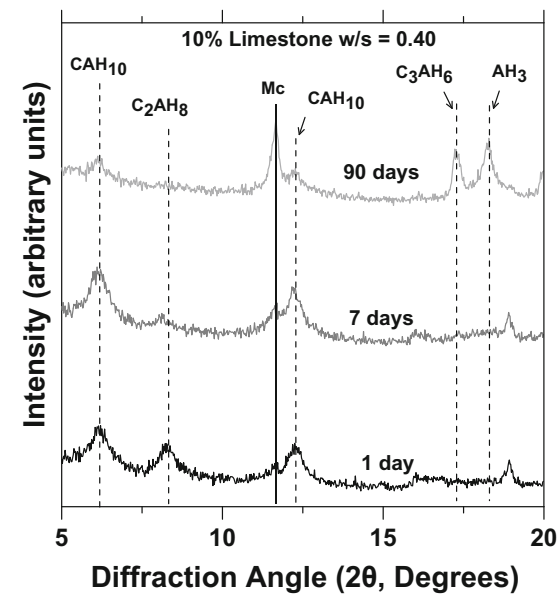

(a)

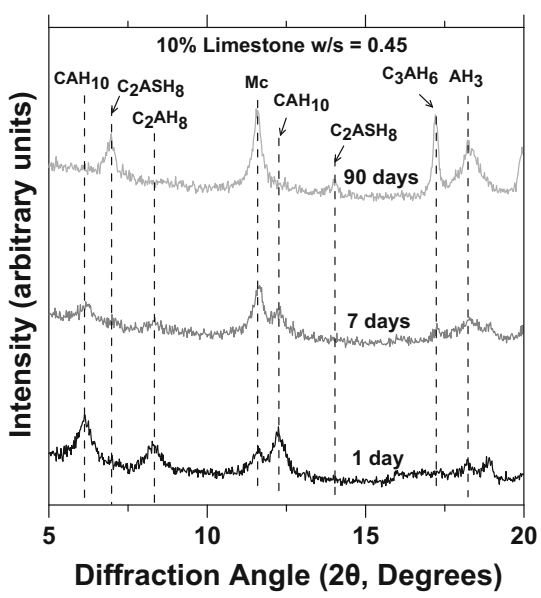

(b)

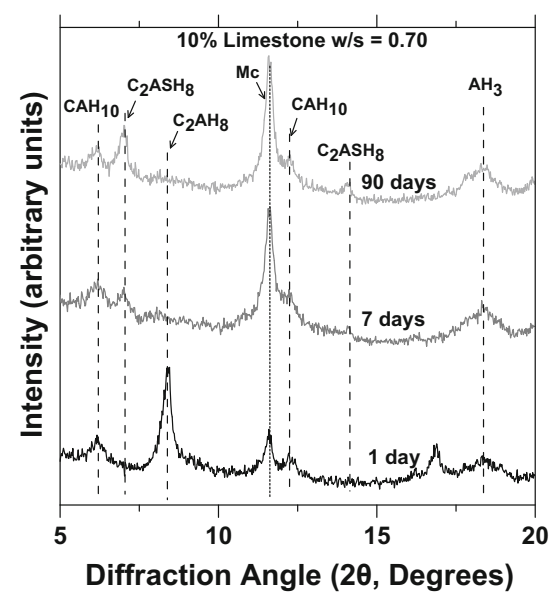

(c)
Figure 3 Representative XRD patterns for the hydrated blends wherein 10 mass \% of CAC has been replaced by limestone for blends prepared at $\mathbf{a} w / \mathrm{s}=0.40, \mathbf{b} w / \mathrm{s}=0.45$, and $\mathbf{c} w / \mathrm{s}=0.70$.
In all plots, $M c$ denotes the monocarboaluminate phase $\left(\mathrm{Ca}_{4} \mathrm{Al}_{2}\left(\mathrm{CO}_{3}\right)(\mathrm{OH})_{12} \cdot 5 \mathrm{H}_{2} \mathrm{O}\right)$. 
$w / s=0.40$. The reduced quantity of $\mathrm{C}_{3} \mathrm{AH}_{6}$ which was noted with increasing $w / s$ is likely on the account of a larger water content which favors the formation of $\mathrm{CAH}_{10}$ and $\mathrm{C}_{2} \mathrm{AH}_{8}$ - whose formation is favored at the expense of $\mathrm{C}_{3} \mathrm{AH}_{6}$ at early ages. In fact, the formation of the $\mathrm{C}_{2} \mathrm{AH}_{8}$ phase serves as a transitory step in the formation of $\mathrm{C}_{3} \mathrm{AH}_{6}[13,14]$.

The XRD patterns shown in Fig. 3 revealed Mc as the only carboaluminate phase (i.e., no Hc is detected) formed independent of $w / s$ or age. This is likely on account of maintenance of a suitable $\left[\mathrm{CO}_{3}{ }^{2-}\right] /$ $\left[\mathrm{OH}^{-}\right]$molar ratio in solution which favors the formation of Mc, at the expense of Hc. This is a significant observation in comparison with OPC systems where Hc initially forms and over time transforms to Mc as calcite dissolution progresses [40]. The formation of strätlingite $\left(\mathrm{C}_{2} \mathrm{ASH}_{8}\right)$ is favored with increasing water availability. The formation of strätlingite suggests the hydration of gehlenite $\left(\mathrm{C}_{2} \mathrm{AS}\right)$, a low reactivity phase [15]. These results, therefore, indicate that the reactivities of both limestone and of $\mathrm{C}_{2} \mathrm{AS}$ and hence the formation of $\mathrm{Mc}$ and $\mathrm{C}_{2} \mathrm{ASH}_{8}$ are enhanced in $\mathrm{CAC}$ blends with a higher water content and water activity [13].

\section{Influence of sodium (highly soluble) carbonate additions}

Figures 5-6 show representative XRD patterns and DTG curves of water-rich $(w / s=0.70)$ CAC blends prepared with sodium carbonate-where 10 and 30 mass $\%$ of the CAC have been replaced by $\mathrm{Na}_{2} \mathrm{CO}_{3}$. Several differences with respect to limestone systems were identified. First, it was noted that, unlike systems containing limestone, an increase in the amount of the carbonate source $\left(\mathrm{Na}_{2} \mathrm{CO}_{3}\right)$ does not increase the amount of the carboaluminate phase formed. Instead, $\mathrm{Na}_{2} \mathrm{CO}_{3}$ appears to combine with $\mathrm{Ca}^{2+}$ ions present in the solution to form gaylussite $\left(\mathrm{Na}_{2}\right.$ $\left.\mathrm{Ca}\left(\mathrm{CO}_{3}\right)_{2} \cdot 5 \mathrm{H}_{2} \mathrm{O}\right)$ and minor amounts of thermonatrite $\left(\mathrm{Na}_{2} \mathrm{CO}_{3} \cdot \mathrm{H}_{2} \mathrm{O}\right)$-whose presence was verified by DTG analyses (Fig. 6), which shows characteristic dehydration and decarbonation peaks for the former at $133{ }^{\circ} \mathrm{C}$ and $720-750{ }^{\circ} \mathrm{C}$, respectively (Eqs. 7a,7b [41]), and for the latter at around $100{ }^{\circ} \mathrm{C}[42,43]$. Since both gaylussite and thermonatrite are "waterrich phases" containing 5 and 1 formula units of water, respectively, the formation of these phases is suppressed in systems that are water deficient (e.g., $w / s=0.40$; see Figs. 5a and 6a).

$$
\begin{aligned}
& \mathrm{Na}_{2} \mathrm{Ca}\left(\mathrm{CO}_{3}\right)_{2} 5 \mathrm{H}_{2} \mathrm{O} \stackrel{133^{\circ} \mathrm{C}}{\longrightarrow} \mathrm{Na}_{2} \mathrm{Ca}\left(\mathrm{CO}_{3}\right)_{2}+5 \mathrm{H}_{2} \mathrm{O} \\
& \mathrm{Na}_{2} \mathrm{Ca}\left(\mathrm{CO}_{3}\right)_{2} \stackrel{720 \text { to } 750^{\circ} \mathrm{C}}{\longrightarrow} \mathrm{Na}_{2} \mathrm{CO}_{3}+\mathrm{CaO}+\mathrm{CO}_{2} \uparrow
\end{aligned}
$$

Significantly, the conversion of metastable calcium aluminate hydrates (i.e., $\mathrm{CAH}_{10}$ and $\mathrm{C}_{2} \mathrm{AH}_{8}$ ) to $\mathrm{C}_{3} \mathrm{AH}_{6}$ occurs despite provision of a carbonate source and water (Figs. $5 \mathrm{c}$ and $6 \mathrm{c}$ ). The amount of Mc present decreases between 7 and 90 days, while quantities of both $\mathrm{C}_{3} \mathrm{AH}_{6}$ and $\mathrm{AH}_{3}$ increase during the same period. This destabilization of Mc with respect to $\mathrm{C}_{3} \mathrm{AH}_{6}$ is not expected-as Mc is anticipated to remain stable (at ambient temperature) with respect to $\mathrm{C}_{3} \mathrm{AH}_{6}$ and the calcium salt, whose anion is contained in the AFm interlayer position. In contrast, in CAC-limestone blends, at high $w / s$ (e.g., for $w / s=0.70$ ), the amount of $\mathrm{C}_{3} \mathrm{AH}_{6}$ present is negligible as compared to the $\mathrm{Mc}$ content (Fig. 3c).

The destabilization of $\mathrm{Mc}$ to $\mathrm{C}_{3} \mathrm{AH}_{6}$ over the course of time in the $\mathrm{Na}_{2} \mathrm{CO}_{3}$-rich systems is speculated to be on account of differences in the binder chemistry. These differences in $\mathrm{Na}_{2} \mathrm{CO}_{3}$ mixtures as compared to $\mathrm{CaCO}_{3}$ systems are likely due to changes in the $\mathrm{CO}_{2 \text {-eq }} / \mathrm{CaO}$ ratio (Fig. 1c) with increasing $\mathrm{CAC}$ replacement. This implies that systems with a higher $\mathrm{CO}_{2-\text { eq }} / \mathrm{CaO}$ ratio form phases with a higher $\mathrm{CO}_{3}{ }^{2-}$ and a lower $\mathrm{Ca}^{2+}$ content (i.e., as compared to $\mathrm{Mc}$ and $\mathrm{Hc}$ ), which in an $\mathrm{Na}^{+}$-concentrated environment results in the formation of gaylussite or thermonatrite. The formation of gaylussite and thermonatrite consumes a large quantity of water (e.g., 5 and 1 molar units of water, respectively, are taken up per formula unit of gaylussite and thermonatrite), which may lead to the formation of $\mathrm{C}_{3} \mathrm{AH}_{6}$ as the dominant stable phase due to its low water content, and simultaneously prevent carboaluminate phase formation. A similar hindrance in $\mathrm{NO}_{3}$-AFm phase formation due to limited water availability was also noted when $\mathrm{Ca}\left(\mathrm{NO}_{3}\right)_{2}$ was used as an agent to suppress conversion in CACs [13] (i.e., to form the favored $\mathrm{NO}_{3}$-AFm phase) suggesting that bulk chemical composition is an insufficient indicator of the ability to prevent conversion-but rather, the amount of water present is also a relevant variable.

Unlike $\mathrm{CaCO}_{3}$-containing systems, blends containing lower $\mathrm{Na}_{2} \mathrm{CO}_{3}$ contents (10 mass\%) show the formation of Hc at early ages (see Fig. 5a, b). The Hc formed converts to Mc at later ages. While such 


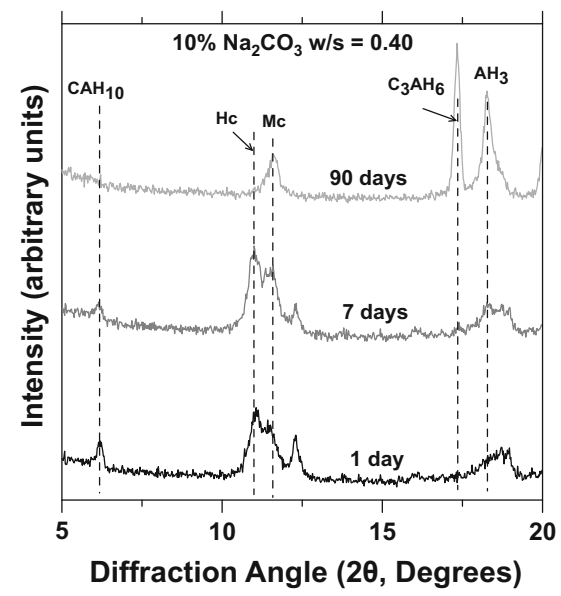

(a)

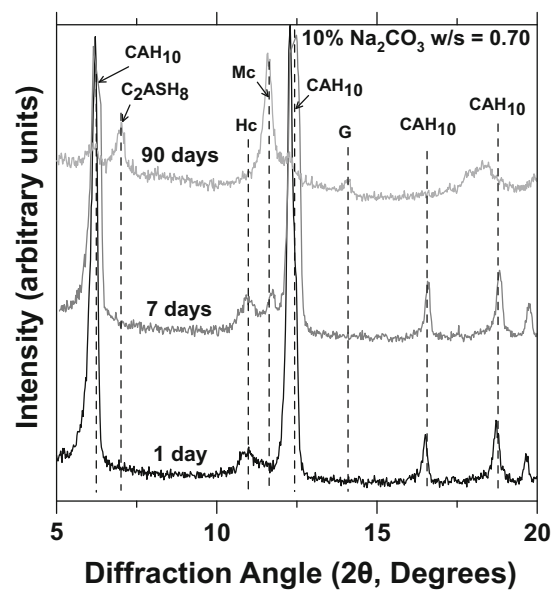

(b)

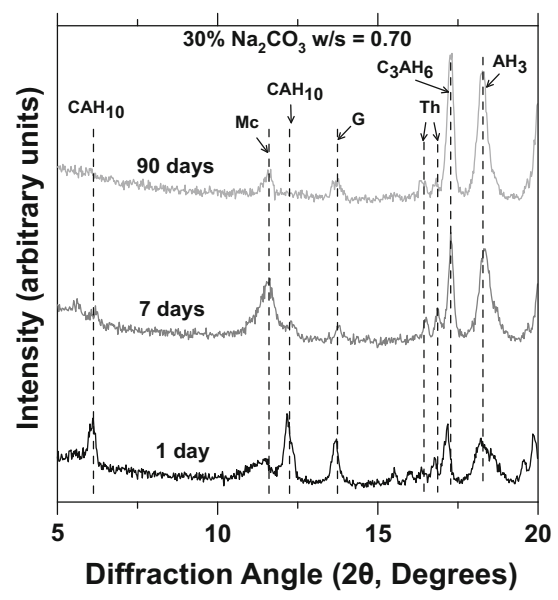

(c)
Figure 5 Representative XRD patterns of the hydrated CAC$\mathrm{Na}_{2} \mathrm{CO}_{3}$ blends for $\mathbf{a} w / s=0.40,10 \% \mathrm{Na}_{2} \mathrm{CO}_{3}, \mathbf{b} w / s=0.70$, $10 \% \mathrm{Na}_{2} \mathrm{CO}_{3}$, and c $w / s=0.70,30 \% \mathrm{Na}_{2} \mathrm{CO}_{3}$. In all plots,
$G$ gaylussite $\left(\mathrm{Na}_{2} \mathrm{Ca}\left(\mathrm{CO}_{3}\right)_{2} \cdot 5 \mathrm{H}_{2} \mathrm{O}\right)$, Th thermonatrite $\left(\mathrm{Na}_{2} \mathrm{CO}_{3}\right.$ $\left.\cdot \mathrm{H}_{2} \mathrm{O}\right), \mathrm{Mc}$ monocarboaluminate $\left(\mathrm{Ca}_{4} \mathrm{Al}_{2}\left(\mathrm{CO}_{3}\right)(\mathrm{OH})_{12} \cdot 5 \mathrm{H}_{2} \mathrm{O}\right)$, and $\mathrm{Hc}$ hemicarboaluminate $\left(\mathrm{Ca}_{4} \mathrm{Al}_{2}\left(\mathrm{CO}_{3}\right)_{0.5}(\mathrm{OH})_{13} \cdot 5.5 \mathrm{H}_{2} \mathrm{O}\right)$.

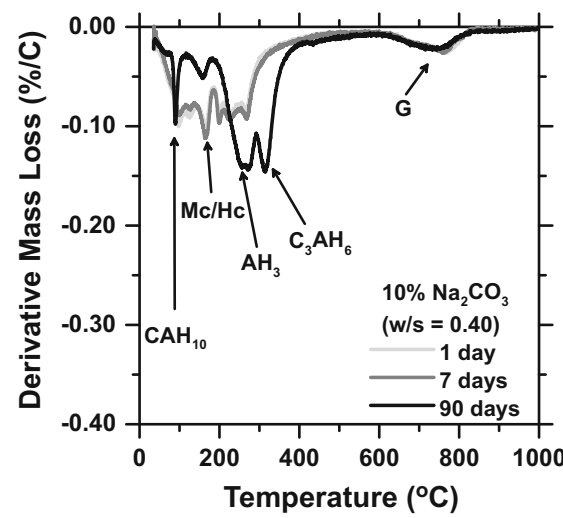

(a)

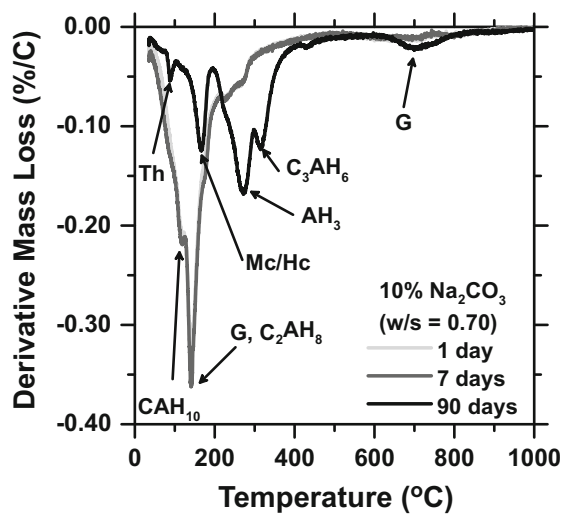

(b)

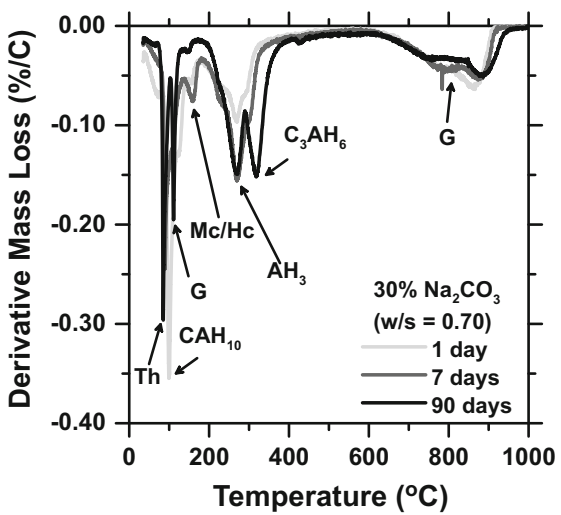

(c)
Figure 6 Representative DTG traces for the hydrated CAC$\mathrm{Na}_{2} \mathrm{CO}_{3}$ blends for $\mathbf{a} w / s=0.40,10 \% \mathrm{Na}_{2} \mathrm{CO}_{3}, \mathbf{b} w / s=0.70$, $10 \% \mathrm{Na}_{2} \mathrm{CO}_{3}$, and c $w / s=0.70,30 \% \mathrm{Na}_{2} \mathrm{CO}_{3}$. In all plots,

behavior is seen in OPC systems containing limestone where the formation of Hc precedes Mc [44], this behavior is not observed in CAC blends with limestone (see Fig. 3) where Mc forms rapidly. Taken together, these results note the relevance of (i) water availability, (ii) solubility of the carbonate source, and (iii) calcium content of the carbonate source as major variables which influence stable phase relations in CAC blends that are hydrated at $25^{\circ} \mathrm{C}$ and under sealed conditions.
$G$ gaylussite $\left(\mathrm{Na}_{2} \mathrm{Ca}\left(\mathrm{CO}_{3}\right)_{2} \cdot 5 \mathrm{H}_{2} \mathrm{O}\right)$, Th thermonatrite $\left(\mathrm{Na}_{2} \mathrm{CO}_{3}\right.$ $\left.\cdot \mathrm{H}_{2} \mathrm{O}\right), \mathrm{Mc}$ monocarboaluminate $\left(\mathrm{Ca}_{4} \mathrm{Al}_{2}\left(\mathrm{CO}_{3}\right)(\mathrm{OH})_{12} \cdot 5 \mathrm{H}_{2} \mathrm{O}\right)$, and $\mathrm{Hc}$ hemicarboaluminate $\left(\mathrm{Ca}_{4} \mathrm{Al}_{2}\left(\mathrm{CO}_{3}\right)_{0.5}(\mathrm{OH})_{13} \cdot 5.5 \mathrm{H}_{2} \mathrm{O}\right)$.

\section{Thermodynamic calculations}

\section{Role of water content on phase equilibria}

A series of thermodynamic calculations were carried out to understand, parametrically, how the water content of a given mixture influences stable phase equilibria when CAC is replaced by a carbonate source. Figure 7 shows equilibrium phase assemblages assessed in blends wherein 10 mass\% of the 


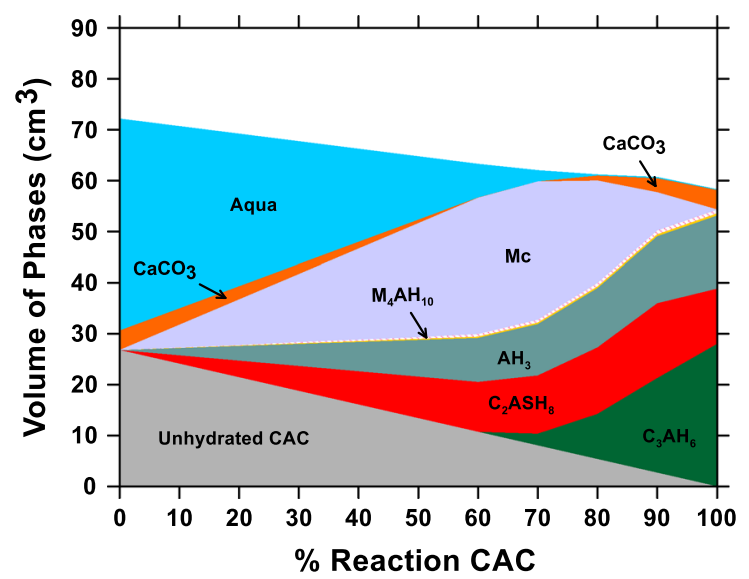

(a)

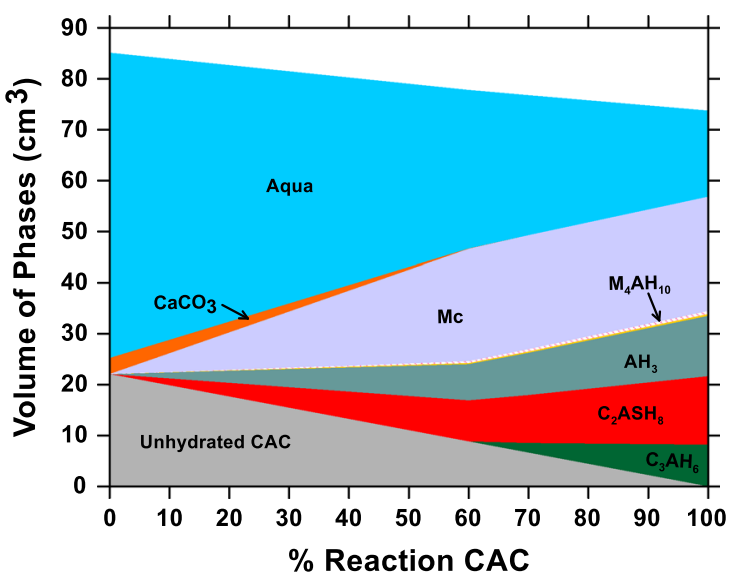

(b)

Figure 7 Volumetric phase assemblage calculated to exist when 10 mass $\% \mathrm{CAC}$ has been replaced by limestone $\left.(\mathrm{CaCO})_{3}\right)$ for a $w /$ $s=0.40$ and $\mathbf{b} w / s=0.70$. In these plots, $M c$ monocarboaluminate $\left(\mathrm{Ca}_{4} \mathrm{Al}_{2}\left(\mathrm{CO}_{3}\right)(\mathrm{OH})_{12} \cdot 5 \mathrm{H}_{2} \mathrm{O}\right)$ and $M_{4} A H_{10} \mathrm{OH}$-hydrotalcite.

CAC has been replaced by limestone. In general, systems prepared at lower $w / s($ e.g., $w / s=0.40)$ show the increasing formation of $\mathrm{Mc}$ and $\mathrm{AH}_{3}$, until water is exhausted (Fig. 7a). The formation of $\mathrm{C}_{3} \mathrm{AH}_{6}$ is prevented so long as free water is available. However, once free water is consumed (around $70 \%$ CAC reaction), Mc decomposes or stops forming, and other phases such as $\mathrm{AH}_{3}, \mathrm{C}_{3} \mathrm{AH}_{6}$, and $\mathrm{CaCO}_{3}$ are expected to precipitate. Such sacrificial behavior of $\mathrm{Mc}$, in favor of $\mathrm{C}_{3} \mathrm{AH}_{6}$ and $\mathrm{CaCO}_{3}$, in water-deficient systems is not observed experimentally as Mc continues to form over time (i.e., as the CAC reaction progresses) despite the low water content (see Fig. 3a)—at least until 90 days. This points to the stability of Mc in CAC-limestone systems, wherein once formed, this phase remains stable in spite of low water availability. It is however possible that the decomposition of Mc into $\mathrm{CaCO}_{3}$ and $\mathrm{C}_{3} \mathrm{AH}_{6}$ occurs at times later than 90 days.

In cases where water is abundant, Mc persists as long as limestone is present (see Fig. $7 \mathrm{~b}$ ). But, when limestone is consumed, expectedly, $\mathrm{C}_{3} \mathrm{AH}_{6}$ forms as a stable phase. In agreement with experimental data (Fig. 3), the calculations predict the formation of $\mathrm{C}_{2} \mathrm{ASH}_{8}$ (strätlingite) due to the $\mathrm{C}_{2} \mathrm{AS}$ hydration, in water-deficient and water-rich systems (Fig. 7). The calculations also suggest that under water-rich and kinetically unconstrained conditions, as long as limestone is present, the conversion process can be mitigated. This is however unrealistic because under practical conditions the ability to suppress conversion when limestone is present is negligible [24]. This discrepancy arises because the calculations due to their equilibrium nature do not account for the slow dissolution of $\mathrm{CaCO}_{3}$-which prevents it from serving as an effective conversion suppression agent. As a result, at any extent of $\mathrm{CAC}$ reaction, the calculations overestimate the amount of $\mathrm{CaCO}_{3}$ consumed, the quantity of Mc formed, and thus the success (or lack thereof) of mitigating the conversion phenomena.

Figure 8 shows equilibrium phase assemblages in water-rich $(w / s=0.70)$ systems where 10 and 30 mass \% CAC have been replaced by $\mathrm{Na}_{2} \mathrm{CO}_{3}$. In these cases, the formation of $\mathrm{C}_{3} \mathrm{AH}_{6}$ is either delayed or negated with rising $\mathrm{Na}_{2} \mathrm{CO}_{3}$ dosages and with an increasing extent of CAC reaction. At modest $\mathrm{Na}_{2}$ $\mathrm{CO}_{3}$ dosages (10 mass\%), $\mathrm{AH}_{3}$ and $\mathrm{Mc}$ are predicted to form (Fig. 8a), the latter by the uptake of $\mathrm{CO}_{3}{ }^{2-}$ species solubilized in the pore fluid, while $\mathrm{Na}^{+}$ remains mobile in the pore solution (N.B.: alkali uptake is not considered herein). When $\mathrm{Na}_{2} \mathrm{CO}_{3}$ dosages are increased, gaylussite $\left(\mathrm{Na}_{2} \mathrm{Ca}\left(\mathrm{CO}_{3}\right)_{2}\right.$ $.5 \mathrm{H}_{2} \mathrm{O}$ ) forms with a corresponding decrease in the amount of $\mathrm{AH}_{3}$ and Mc present-in agreement with XRD and DTG data as shown in Figs. $5 c$ and $6 c$, respectively. The formation of gaylussite is ensured by the need to allocate sodium and carbonate species, which in turn penalizes the formation of Mc (see Fig. $8 b$ ).

The formation of water-rich phases (gaylussite and thermonatrite), and their resultant water uptake, does not trigger the formation of $\mathrm{C}_{3} \mathrm{AH}_{6}$ (a dense, lowwater content phase) as seen in the XRD data (a Fig. 5c) and Mc continues to form unimpeded 


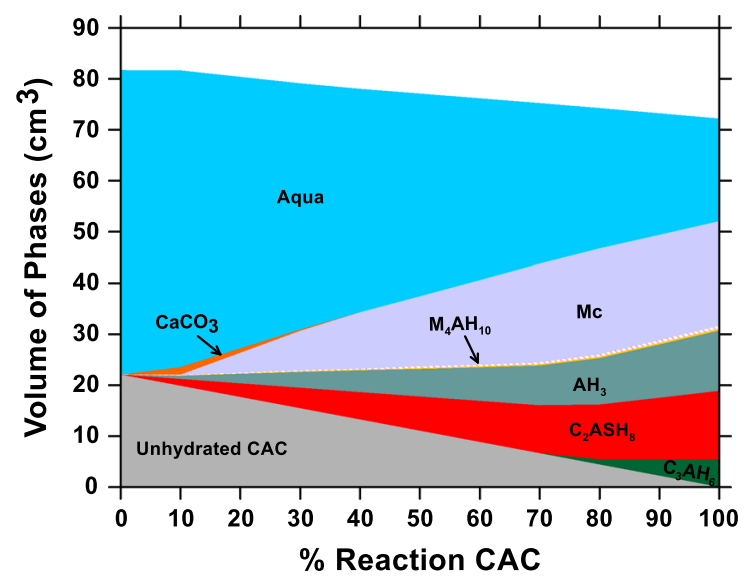

(a)

Figure 8 Volumetric phase assemblage calculated to exist for $w /$ $s=0.70$ when $\mathrm{CAC}$ has been replaced by $\mathrm{Na}_{2} \mathrm{CO}_{3}$ at the level of (by mass) a 10 mass $\%$ and $\mathbf{b} 30$ mass $\%$. In these plots,

(Fig. 8). While the reasons for this discrepancy are not fully clear, it is thought to be on account of the calculations being unable to account for the water activity-dependent stability of Mc, which destabilizes below a critical water activity $[45,46]$, or due to $\mathrm{C}_{3} \mathrm{AH}_{6}$ formation in inhomogeneous microstructural zones. Water activity is discussed, as the solubilization of $\mathrm{Na}_{2} \mathrm{CO}_{3}$ into the mixing water would result in significant reductions in the water activity. It is seen that thermonatrite $\left(\mathrm{Th}, \mathrm{Na}_{2} \mathrm{CO}_{3} \cdot \mathrm{H}_{2} \mathrm{O}\right)$, although present in the XRD data (Fig. 5c), is absent in the predicted phase assemblages at equilibrium (Fig. 8b). This is thought to be because thermonatrite forms at the time of early CAC hydration, i.e., when $\mathrm{Na}_{2} \mathrm{CO}_{3}$ is added to the mixing water and remains unaffected thereafter (e.g., see near-constant thermonatrite intensities in the XRD patterns across all ages).

\section{Role of the calcium content of the carbonate source}

To estimate the effects of the "calcium content" of the carbonate source, a new series of simulations were carried out. Here, the level of CAC replacement (by a carbonate source) varies between 0 and 50 mass\%. At each replacement increment, a process simulation was carried out, in which the amount of carbonate source was progressively reduced while increasing the $\mathrm{CaO}$ content of the system, i.e., to simulate the influence of $\mathrm{CaO}$ that could accompany the carbonate salt. In these calculations, the quantity of the carbonate source and additional $\mathrm{CaO}$ provided (i.e., over

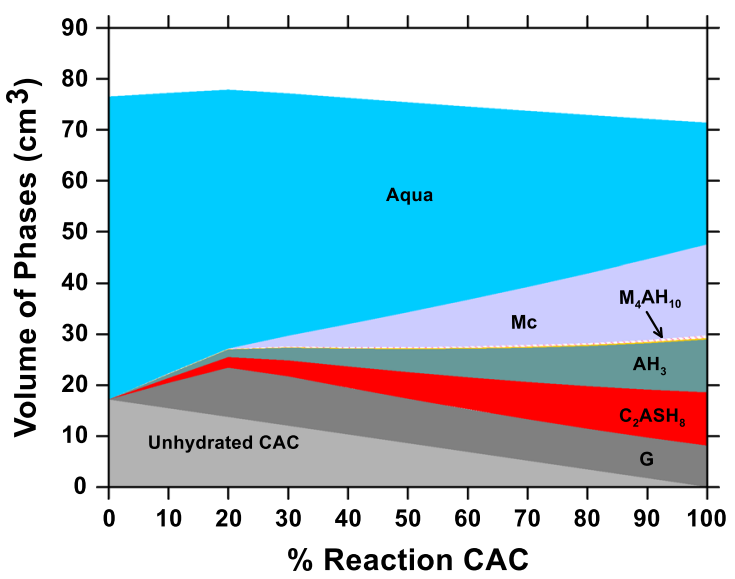

(b)

$G$ gaylussite $\left(\mathrm{Na}_{2} \mathrm{Ca}\left(\mathrm{CO}_{3}\right)_{2} \cdot 5 \mathrm{H}_{2} \mathrm{O}\right), M c$ monocarboaluminate $\left(\mathrm{Ca}_{4} \mathrm{Al}_{2}\left(\mathrm{CO}_{3}\right)(\mathrm{OH})_{12} \cdot 5 \mathrm{H}_{2} \mathrm{O}\right)$, and $\mathrm{M}_{4} A H_{10} \mathrm{OH}$-hydrotalcite.

and above $\mathrm{CaO}$ contributed by the $\mathrm{CAC}$ ) was fixed according to the level of CAC replacement. For example, in the case of a 30 mass\% CAC replacement, the CaO-to-carbonate source ratio (see $x$-axis in Fig. 9) ranges from 0.93 to 18.30 for both carbonate sources $\left(\mathrm{Na}_{2} \mathrm{CO}_{3}\right.$ and $\left.\mathrm{CaCO}_{3}\right)$.

Figure 9 shows the volumetric phase assemblage as a function of an increase in the CaO-to-carbonate source ratio. It is seen that the phase assemblage alters significantly as $\mathrm{CaO} / \mathrm{XCO}_{3}$ ratio (where $\mathrm{X}=\mathrm{Ca}, \mathrm{Na}_{2}$ ) increases. Specifically, the amount of Mc produced, by both carbonate sources, initially increases and then reaches a maximum at a $\mathrm{CaO} /$ $\mathrm{XCO}_{3} \approx 2.0$ and decreases thereafter. $\mathrm{CaCO}_{3}$ is slightly more efficient than $\mathrm{Na}_{2} \mathrm{CO}_{3}$ in forming $\mathrm{Mc}$ at a similar $\mathrm{CaO} / \mathrm{XCO}_{3}$ value on account of (a) its greater provision of $\mathrm{Ca}^{2+}$ ions when $\mathrm{X}=\mathrm{Ca}$ than $\mathrm{X}=\mathrm{Na}$, and (b) limestone's low solubility which implies that water activity of the pore fluid is higher when $X=\mathrm{Ca}$ than $X=\mathrm{Na}$, a condition that potentially favors the formation of Mc. This points to the relevance of the carbonate source's calcium content and its solubility as factors controlling carboaluminate phase formation in CAC systems.

\section{Summary and conclusions}

The influences of slightly $\left(\mathrm{CaCO}_{3}\right)$ and highly soluble $\left(\mathrm{Na}_{2} \mathrm{CO}_{3}\right)$ carbonate salts on hydrated phase relations in calcium aluminate cements (CACs) have been critically examined. It has been shown that water 


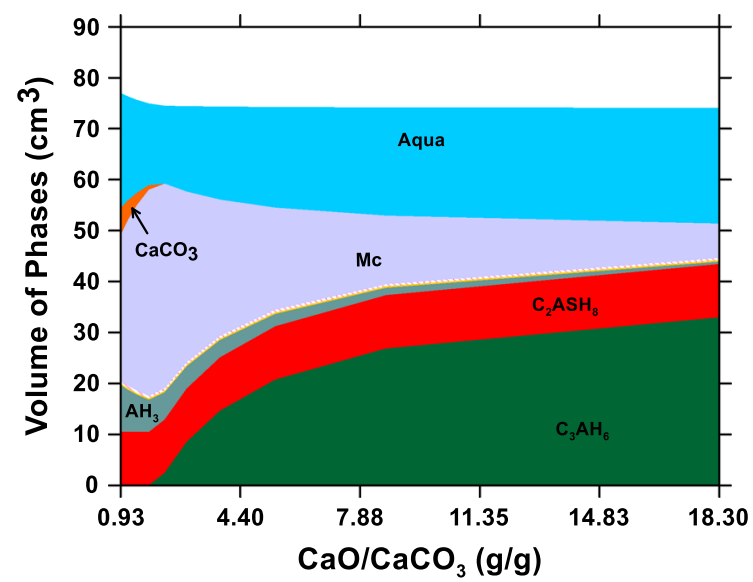

(a)

Figure 9 Volumetric phase assemblage calculated to exist for $w /$ $s=0.70$ when 30 mass $\%$ of the $\mathrm{CAC}$ has been replaced by a combination of $\mathbf{a} \mathrm{CaO}$ and $\mathrm{CaCO}_{3}$ and $\mathbf{b} \mathrm{CaO}$ and $\mathrm{Na}_{2} \mathrm{CO}_{3}$. In

availability and the solubility and calcium content of the carbonate source play important and interrelated roles in the formation of carboaluminate phases. In the case of slightly soluble carbonates $\left(\mathrm{CaCO}_{3}\right)$, a higher water availability (and water activity) is linked to an increase in carbonate source consumption and carboaluminate (Mc) phase formation. These conclusions are supported by experimental observations of thermogravimetric and X-ray diffraction datasets. Comparisons between thermodynamic calculations and experimental results reveal that $\mathrm{CaCO}_{3}$ consumption is limited due to the low aqueous solubility and dissolution rate of $\mathrm{CaCO}_{3}$ - which are the limiting factors in carboaluminate phase formation.

To overcome the limitations of $\mathrm{CaCO}_{3}$ use, a soluble carbonate salt $\left(\mathrm{Na}_{2} \mathrm{CO}_{3}\right)$ was studied as a potentially more reactive carbonate source. Despite its high solubility, thermogravimetric and X-ray diffraction data show that $\mathrm{Na}_{2} \mathrm{CO}_{3}$ also fails to boost carboaluminate phase formation. In this case, the formation of other carbonate-bearing phases (i.e., gaylussite and thermonatrite) that compete for $\mathrm{CO}_{3}{ }^{2-}$ ions suppress carboaluminate phase formation. The formation of these other carbonate phases (i.e., which lack aluminum and feature a lower $\mathrm{Ca}^{2+}$ content as compared to the carboaluminate hydrates), and the persistence of $\mathrm{AH}_{3}$ in $\mathrm{Na}_{2} \mathrm{CO}_{3}$ systems, indicates that the calcium content of the carbonate source is a key variable which influences carboaluminate phase formation. It is noted that reductions in water activity resulting from the solubilization of ions negatively

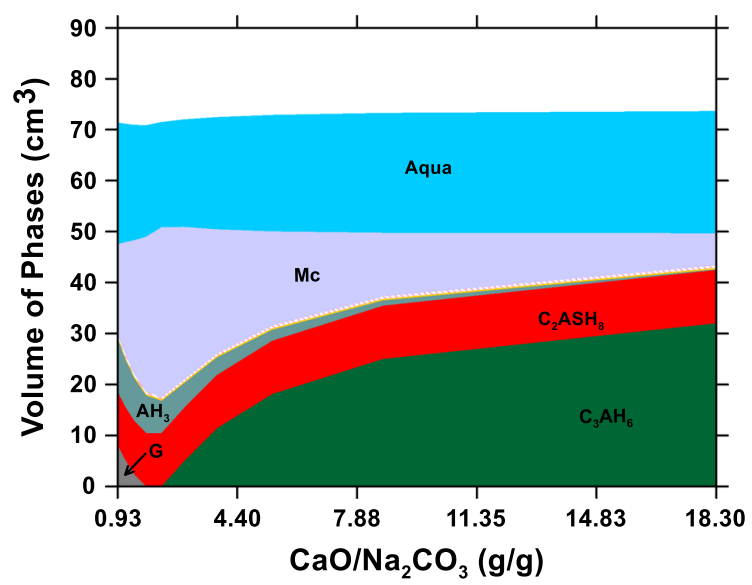

(b)

these plots, $\mathrm{G}$ gaylussite $\left(\mathrm{Na}_{2} \mathrm{Ca}\left(\mathrm{CO}_{3}\right)_{2} \cdot 5 \mathrm{H}_{2} \mathrm{O}\right), M c$ monocarboaluminate $\left(\mathrm{Ca}_{4} \mathrm{Al}_{2}\left(\mathrm{CO}_{3}\right)(\mathrm{OH})_{12} \cdot 5 \mathrm{H}_{2} \mathrm{O}\right)$, and $M_{4} A H_{10} \mathrm{OH}-$ hydrotalcite.

affect carboaluminate phase formation. It is thus concluded that, independent of the carbonate salt used, carboaluminate phase formation is not a viable solution to mitigate conversion phenomena in hydrated CACs.

\section{Acknowledgements}

The authors acknowledge the financial support for this research provisioned by the University of California, Los Angeles (UCLA), and National Science Foundation (CMMI: 1066583). The authors also acknowledge the provision of materials by OMYA A.G. and Kerneos Aluminate Technologies. The contents of this paper reflect the views and opinions of the authors who are responsible for the accuracy of the datasets presented herein. This research was conducted in the Laboratory for the Chemistry of Construction Materials ( $\mathrm{LC}^{2}$ ) and Molecular Instrumentation Center (MIC) at the University of California, Los Angeles (UCLA). As such, the authors gratefully acknowledge support that has made these laboratories and their operations possible.

\section{References}

[1] De Weerdt K, Ben Haha M, Le Saout G et al (2011) Hydration mechanisms of ternary Portland cements containing limestone powder and fly ash. Cem Concr Res 41(3):279-291 
[2] Damidot D, Glasser FP (1995) Thermodynamic investigation of the $\mathrm{CaO}-\mathrm{Al}_{2} \mathrm{O}_{3}-\mathrm{CaSO}_{4}-\mathrm{CaCO}_{3}-\mathrm{H}_{2} \mathrm{O}$ closed system at $25^{\circ} \mathrm{C}$ and the influence of $\mathrm{Na} 2 \mathrm{O}$. Adv Cem Res 7(27):129-134

[3] Damidot D, Lothenbach B, Herfort D, Glasser FP (2011) Thermodynamics and cement science. Cem Concr Res 41(7):679-695

[4] Kumar A, Oey T, Kim S, Thomas D, Badran S, Li J, Fernandes F, Neithalath N, Sant G (2013) Simple methods to estimate the influence of limestone fillers on reaction and property evolution in cementitious materials. Cem Concr Compos 42:20-29

[5] Lothenbach B, Winnefeld F (2006) Thermodynamic modelling of the hydration of Portland cement. Cem Concr Res 36(2):209-226

[6] Lothenbach B, Le Saout G, Gallucci E, Scrivener K (2008) Influence of limestone on the hydration of Portland cements. Cem Concr Res 38(6):848-860

[7] Matschei $\mathrm{T}$ (2007) Thermodynamics of cement hydration $\mathrm{PhD}$ diss., Aberdeen University, Aberdeen

[8] Matschei T, Lothenbach B, Glasser FP (2007) The AFm phase in Portland cement. Cem Concr Res 37(2):118-130

[9] Oey T, Kumar A, Bullard JW, Neithalath N, Sant G (2013) The filler effect: the influence of filler content and surface area on cementitious reaction rates. J Am Ceram Soc 96(6):1978-1990

[10] Tomaž V, Tinta V, Gabrovšek, Kaučič V (2001) The effects of limestone addition, clinker type and fineness on properties of Portland cement. Cem Concr Res 31(1):135-139

[11] Tsivilis S, Chaniotakis E, Kakali G, Batis G (2002) An analysis of the properties of Portland limestone cements and concrete. Cem Concr Compos 24(3):371-378

[12] Puerta-Falla G, Balonis M, Le Saout G, Falzone G, Zhang C, Neithalath N, Sant G (2015) Elucidating the role of the aluminous source on limestone reactivity in cementitious materials. J Am Ceram Soc 98(12):4076-4089

[13] Falzone G, Balonis M, Sant G (2015) X-AFm stabilization as a mechanism of bypassing conversion phenomena in calcium aluminate cements. Cem Concr Res 72:54-68

[14] Lothenbach B, Pelletier-Chaignat L, Winnefeld F (2012) Stability in the system $\mathrm{CaO}-\mathrm{Al}_{2} \mathrm{O}_{3}-\mathrm{H}_{2} \mathrm{O}$. Cem Concr Res 42(12):1621-1634

[15] Scrivener KL, Capmas A (1998) Lea's Chemistry of cement and concrete calcium aluminate cements, Chapter 13, In: Hewlett PC (ed), Wiley, New York

[16] Scrivener KL, Cabiron JL, Letourneux R (1999) High-performance concretes from calcium aluminate cements. Cem Concr Res 29(8):1215-1223

[17] Puerta-Falla G, Kumar A, Gomez-Zamorano L, Bauchy M, Neithalath N, Sant G (2015) The influence of filler type and surface area on the hydration rates of calcium aluminate cement. Constr Build Mater 96:657-665

[18] Klaus SR, Neubauer J, Goetz-Neunhoeffer F (2013) Hydration kinetics of $\mathrm{CA}_{2}$ and $\mathrm{CA}$ - investigations performed on a synthetic calcium aluminate cement. Cem Concr Res 43:62-69

[19] Taylor HFW (1997) Cement Chemistry, 2nd edn. Thomas Telford, London

[20] Mangabhai RJ, Glasser FP (2001) Calcium Aluminate Cements. IOM communications, London

[21] Shahwana R, Barnes P, Bensted J, Turrillas X (1994) Conversion of calcium aluminate cement hydrates re-examined with synchrotron energy-dispersive diffraction J Mater Sci lett 13(17):1232-1234

[22] Ukrainczyk N, Šipušić J, Dabić P, Matusinović T (2008) Microcalorimetric study on calcium aluminate cement hydration. 13th International conference on materials, processes, friction and wear, p 382-388

[23] Kuzel HJ (1996) Initial hydration reactions and mechanisms of delayed ettringite formation in Portland cements. Cem Concr Compos 18(3):195-203

[24] Luz AP, Pandolfelli VC (2012) $\mathrm{CaCO}_{3}$ addition effect on the hydration and mechanical strength evolution of calcium aluminate cement for endodontic applications. Ceram Int 38(2):1417-1425

[25] ASTM (International and American Society for Testing \& Materials) (2004) Annual book of ASTM standards, American Society for Testing \& Materials, USA

[26] National Center for Biotechnology Information (NCBI)PubChem database. Available at https://www.ncbi.nlm.nih. gov/pccompound. Accessed 10 Dec 2015

[27] FIZ/NIST-Inorganic crystal structure database (ICSD) (version 2009/1). Available for purchase at http://www.nist. gov/srd/nist84.cfm

[28] Mineralogical Society of America-American mineralogist crystal structure database. Available at http://rruff.geo.ari zona.edu/AMS/amcsd.php. Accessed 15 Jan 2015

[29] Le Saout G, Kocaba V, Scrivener KL (2011) Application of the Rietveld method to the analysis of anhydrous cement. Cem Concr Res 41:133-148

[30] Kulik D (2013) GEMS-PSI 2.1. Available at http://les.web. psi.ch/Software/GEMS-PSI/. Accessed 18 June 2013

[31] Myers RJ, Lothenbach B, Bernal SA, Provis JL (2015) Thermodynamic modelling of alkali-activated slag cements. Appl Geochem 61:233-247

[32] Martin LHJ, Winnefeld F, Müller CJ, Lothenbach B (2015) Contribution of limestone to the hydration of calcium sulfoaluminate cement. Cem Concr Compos 62:204-211

[33] Thomas JJ, Jennings HM (1998) Free-energy-based model of chemical equilibria in the $\mathrm{CaO}-\mathrm{SiO}_{2}-\mathrm{H}_{2} \mathrm{O}$ system. J Am Ceram Soc 81(3):606-612 
[34] Paul Scherrer Institute-GEMS: Gibbs free energy software for geochemical modeling. Available at http://gems.web.psi. ch/. Accessed 18 June 2015

[35] Lothenbach B - CEMDATA. Available at http://www.empa. ch/web/s308/cemdata. Accessed 18 June 2014

[36] Haha MB, Lothenbach B, Le Saout G, Winnefeld F (2012) Influence of slag chemistry on the hydration of alkali-activated blast-furnace slag-Part II: effect of $\mathrm{Al}_{2} \mathrm{O}_{3}$. Cem Concr Res 42(1):74-83

[37] Pelletier-Chaignat L, Winnefeld F, Lothenbach B, Müller CJ (2012) Beneficial use of limestone filler with calcium sulphoaluminate cement . Constr Build Mater 26(1):619-627

[38] Geoscience for a sustainable earth-Mineral species data base. Available at http://thermoddem.brgm.fr/data/mineraux. php. Accessed on 15 Jan 2015

[39] Önder K, Yaman IO, Tokyay M (2013) Compressive strength development of calcium aluminate cement-GGBFS blends. Cem Concr Compos 35(1):163-170

[40] Lothenbach B, Le Saout G, Gallucci E, Scrivener K (2008) Influence of limestone on the hydration of Portland cements. Cem Concr Res 38(6):848-860
[41] Johnson DR, Robb WA (1973) Gaylussite: thermal properties by simultaneous thermal analysis. Am Mineral 58:778-784

[42] Hartmant M, Trnka O, Vesely V, Karel Svodoba (2001) Thermal dehydration of the sodium carbonate hydrates. Chem Eng Commun 185(1):1-16

[43] Steudel A, Mehl D, Emmerich K (2013) Simultaneous thermal analysis of different bentonite-sodium carbonate systems: an attempt to distinguish alkali-activated bentonites from raw materials. Clay Miner 48(1):117-128

[44] Matschei T, Lothenbach B, Glasser FP (2007) The role of calcium carbonate in cement hydration. Cem Concr Res 37(4):551-558

[45] Baquerizo LG, Matschei T, Scrivener KL, Saeidpour M, Wadsö L (2015) Hydration states of AFm cement phases. Cem Concr Res 73:143-157

[46] Baquerizo LG (2015) Impact of water activity on the mineralogy of hydrated cement Ph.D. diss. École Polytechnique Fédérale de Lausanne, Lausanne 